\title{
Novel Sphincter-preserving Therapies for Recurrent Anal Fistulas
}

\section{Tekrarlayan Anal Fistüller için Yeni Sfinkter Koruyucu Tedaviler}

\author{
(1) Jacek Hermann1, (1) Jarosław Cwaliński1, (1) Tomasz Banasiewicz1, (1) Barbara Kołodziejczak2 \\ 1Poznań University of Medical Sciences, Department of General and Endocrynologic Surgery, and Gastroenterologic Oncology, Poznań, Poland \\ ${ }^{2}$ Adam Mickiewicz University Faculty of Mathematics and Computer Science, Poznań, Poland
}

\section{HII\|III ABSTRACT}

Aim: There is still a need for more effective methods of treatment for the patients with recurrent, crypto-glandular anal fistulas due to a high rate of recurrences with threatening risk of fecal incontinence. The aim of this study was to compare the rate of fistula healing after application of either platelet-rich plasma (PRP) or porcine-derived paste (PDP).

Method: Medical records of 50 patients with anal fistulas were retrospectively evaluated. The patients were divided into two groups. Group I, treated with PRP, consisted of 25 patients, whereas the group II, supplied with PDP consisted also of 25 patients. Fistula closure evaluated clinically was the primary endpoint of the study.

Results: Closure of anal fistulas was achieved in 16 (64\%) patients from the group I, and in 9 (36\%) from the group II and that difference was statistically significant $(\mathrm{p}=0.048)$. There was no significant difference between both groups regarding demographic characteristics except for higher mean age of the patients within the group I ( $\mathrm{p}=0.010)$.

Conclusion: Preliminary results of PRP application in the patients with recurrent, crypto-glandular anal fistulas showed a higher rate of fistulas closure compared to the treatment with PDP.

Keywords: Crypto-glandular anal fistula, platelet-rich plasma, porcine-derived paste

\section{|IIIIIII| ÖZ}

Amaç: Fekal inkontinans riski ile birlikte yüksek nüks oranları nedeniyle tekrarlayan, kripto-glandüler anal fistülü olan hastalarda daha etkili tedavi yöntemlerine hala ihtiyaç vardır. Bu çalışmanın amacı, plateletten zengin plazma (PZP) veya domuzdan elde edilen macun (DEM) uygulamasından sonra fistül iyileşme oranını karşılaştırmaktı.

Yöntem: Anal fistülü olan 50 hastanın tıbbi kayıtları geriye dönük olarak değerlendirildi. Hastalar iki gruba ayrıldı. PZP ile tedavi edilen Grup 1 ve DEM ile tedavi edilen grup 2 25'er hastadan oluşuyordu. Klinik olarak değerlendirilen fistül kapanması çalışmanın birincil sonlanım noktasıydı.

Bulgular: Grup l'den 16 (\%64), grup 2'den 9 (\%36) hastada anal fistül kapatıldı ve bu fark istatistiksel olarak anlamlıydı (p=0,048). Grup l'deki hastaların yaş ortalamalarının yüksek olması dışında her iki grup arasında demografik özellikler açısından anlamlı fark yoktu (p=0,010).

Sonuç: Tekrarlayan, kripto-glandüler anal fistülü olan hastalarda PZP uygulamasının ilk sonuçlarına göre, DEM ile tedaviye kıyasla daha yüksek oranda fistül kapanması sağlanmıştır.

Anahtar Kelimeler: Kripto-glandüler anal fistül, plateletten zengin plazma, domuzdan elde edilen macun

\section{Introduction}

Anal fistulas remain a challenge to surgeons because of their high recurrence rate. ${ }^{1}$ A refractory disease course might prompt multiple surgical interventions with possible risk of damage to the anal sphincters with subsequent faecal incontinence. Therefore, patients should receive conservative treatment. ${ }^{2}$ Consequently, at present, several sphincter-saving methods are offered, such as mucosal advancement flap (MAF) and ligation of intersphincteric

Address for Correspondence/Yazışma Adresi: Jacek Hermann, MD, 
fistula tract (LIFT) or less invasive ones, such as videoassisted anal fistula treatment (VAAFT), negative pressure wound therapy (NPWT), setons, fibrins and plugs, but associated with a higher risk of recurrence. An attempt to close the internal opening without jeopardising the function of the sphincter is a major advantage of those methods. ${ }^{3}$ Application of platelet-rich plasma (PRP) or porcinederived paste (PDP) has appeared recently in the field of anal fistula therapy. PRP is an autologous product obtained from the whole blood. The value of plasma lies on its ability to soak the adjacent soft tissues relative to fistulous tract with high concentration of platelet-derived growth factors to accelerate the healing process. ${ }^{4}$ By contrast, PDP consists of collagen retrieved from porcine dermis, which becomes a scaffold promoting formation of a fresh granulation tissue and subsequent fistula closure. ${ }^{5}$ This study aimed to assess preliminary results of recurrent anal fistula treatments with PRP in comparison with PDP.

\section{Method}

Medical records of 50 patients with primary or recurrent high anal fistulas of cryptoglandular origin treated between 2017 and 2020 were retrospectively evaluated. Patients were divided into two groups: The PRP group consisted of 25 patients, including 13 (52\%) male and 12 (48\%) female, with median age of 32 [interquartile range (IQR): 29-39] years. The PDP group consisted of 25 patients, including 14 (56\%) male and 11 (44\%) female, with median age of 38 (IQR: 32-41) years. Previous anal operations such as excision, fistulotomy, MAF and LIFT were performed in 19 (76\%) patients from the PRP group and in 18 (72\%) patients from the PDP group (Table 1). Patients underwent digital rectal examination and probing and/or dyeing of fistulous tracts under anaesthesia. High trans-sphincteric fistulas were diagnosed if more than the lower one-third of the anal sphincter was involved. ${ }^{2}$ Application of either PRP or PDP was preceded with loose seton pre-treatment in all patients with purulent discharge. Then, application of bio-products was preferred for patients with a relatively long and narrow fistulous tract and with a small bore internal orifice, especially if PDP application was considered. The use of PRP or PDP depends on the surgeon and type of anal fistula. The length of the fistulous tract and the diameter of the internal opening were assessed after digital rectal examination. Curettage and cauterisation of fistulous tracts to remove the epithelium and infected granulation tissue, followed by irrigation of those canals, trimming of external orifices and simple closure of the internal orifice, were performed in all patients. The procedure was accomplished with application of PRP in the first group and PDP in the latter group. Then, $15 \mathrm{~mL}$ of whole blood was centrifuged just before the procedure to obtain $1 \mathrm{~mL}$ of PRP, using a commercial kit (Xerthra PRP Kit, Biovico, Poland). The concentrate was administered into adjacent tissues surrounding fistulous tracts, beginning from the internal orifice towards the external orifice. The penetration depth was controlled with the index inserted into the anal canal or by transrectal ultrasonography (TRUS). The procedure was repeated three times every fortnight according to the protocol until the therapeutic effect was achieved, and applications can be repeated if it was clinically justified. Then, a fistulous canal was filled with the paste Permacol (Covidien, Mansfield,

Table 1. Characteristics of the patients

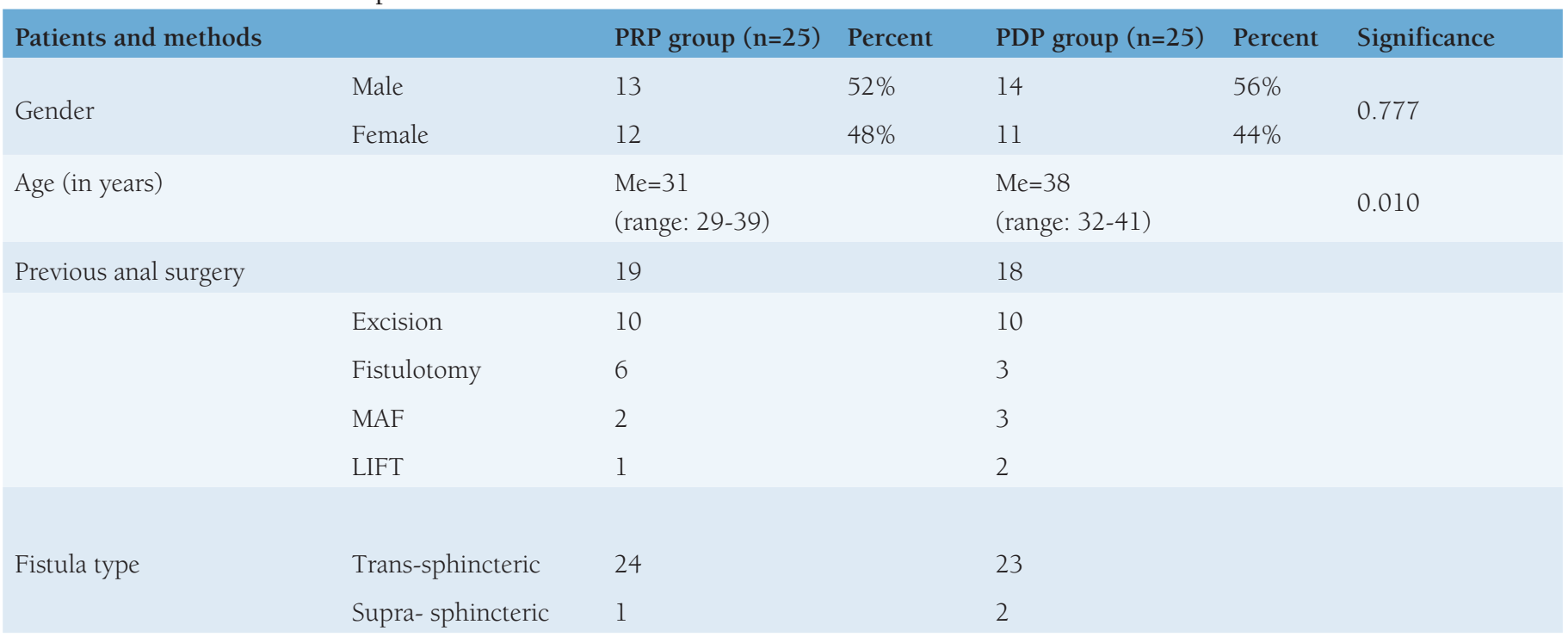


MA) in one procedure. The external orifices were left open in all patients. Fistula closure was defined as the absence of discharge after gentle finger compression of an external orifice and of perianal tissues. The closure was confirmed by TRUS. ${ }^{6}$ Patients were evaluated in an outpatient department within 1, 6 and 12 months following final PRP or PDP application. The evaluation consisted of digital rectal examination, TRUS and completion of the Wexner questionnaire. ${ }^{7}$ Patients with non-cryptoglandular fistulas, e.g. Crohn's, post-radiation and cancerous anal fistulas, were excluded from this investigation.

\section{Statistical Analysis}

Analysed data were presented as medians with range or IQR. Categorical data were presented as percentages. Differences in components of demographic characteristics among two groups were detected by Mann-Whitney U tests or chisquare test. The chi-square test was also used to examine the significance of the fistula closure rate between the groups. Changes in the Wexner score within and between groups were identified by Wilcoxon signed-rank tests or MannWhitney U tests, respectively. A p-value less than 0.05 was considered significant. All analyses were performed using the statistical package STATISTICA v. 13.1 (Stat Soft. Inc., Tulsa, OK, USA). The application of PRP and PDP in anal fistulas was approved by the Bioethics Committee at the University. All participants/patients signed an informed consent before this study.

\section{Results}

Complete closure of anal fistulas was achieved in 16 (64\%) patients from the PRP group compared with 9 (36\%) patients from the PDP group, and the difference was significant $(\mathrm{p}=0.048)$. The healing time ranged from 4 to 8 weeks in the PRP group with application of PRP repeated 3-5 times. Closure of anal fistulas in the PDP group occurred within 4-12 weeks. In the PRP group, anal fistula remained closed in 19 patients at the sixth month and in 16 patients at the $12^{\text {th }}$ month, but were healed in 11 and 9 patients in the PDP group, respectively. No significant difference in demographic characteristics was found between the groups, except for the higher mean age of the patients in the PRP group ( $\mathrm{p}=0.010)$. Mild to moderate form of faecal incontinence, such as gases or liquid stools, was recognised in half of the patients from both groups before therapy and the change in the Wexner score after treatment was not significant ( $P R P, p=0.120$; PDP, $\mathrm{p}=0.065$ ).

\section{Discussion}

Conservative surgery is indicated for most complex and recurrent anal fistulas because of the high recurrence rates and avoidance of damage to the sphincters with subsequent faecal incontinence. Several sphincter-saving methods such as MAF, LIFT, VAAFT, NPWT, fibrins and plugs have been introduced recently. ${ }^{3}$ All these methods, except for MAF with efficacy approaching $50 \%$, require further clinical investigation, since representative randomised trials have not yet been available. ${ }^{8}$ As regards LIFT, it relies on the identification of the space between the internal and external sphincters and on mobilisation and partial excision of the fistulous tract within that space. The efficacy of LIFT is below $50 \% .{ }^{9}$ By contrast, VAAFT enables accurate debridement of fistulous tracts under sight control and closure of the internal opening. Equipment costs are major disadvantages of VAAFT. However, preliminary results of VAAFT are encouraging, with more than half of fistula closure. ${ }^{10}$ Vacuum therapy shows its potential for the management of anal fistulas. NPWT can be defined as a sphincter-saving procedure, because the anal sphincter is left intact. Moreover, it is a more effective kind of surgical drainage than use of loose setons. ${ }^{11}$ With regard to fibrins, the fistulous tract is sealed with fibrin glue, starting from the external opening. A major advantage is the opportunity to repeat the procedure several times as necessary. The low efficacy of fibrins of $14 \%-60 \%$ is a major drawback. ${ }^{12}$ Conversely, a plug is a bioabsorbable prosthesis made from porcine intestinal submucosa. It serves as scaffolding for host cell proliferation. As major advantage, it can be performed multiple times, but its efficacy is approximately $30 \%$ because of frequent rejections. ${ }^{13}$ The PDP consists of collagen type I and elastin fibres retrieved from porcine dermis. During the manufacturing process, cells are removed to reduce immunological response against foreign antigens. The collagen also undergoes cross-linking, which results in increased resistance to degradation, reduction of tissue antigenicity, higher durability and greater strength. Importantly, the paste is a slowly absorbable material, and the collagen becomes a scaffold that enables cellular infiltration and neovascularisation. The dissolution process takes on average a few months, after which the paste is replaced with patient's dense and strong scar tissue. If compared with synthetic pastes, biological pastes induce milder inflammatory response and a more orderly collagen deposition. In addition, the cross-linked materials showed greater resistance to collagenase digestion. The major drawback is the relatively low efficacy, mainly due to frequent leakage of the paste from the fistulous tract before the occurrence of cellular infiltration and neovascularisation. ${ }^{5,14}$ PRP is an autologous product obtained from whole blood through gradient density centrifugation. Results achieved after PRP application were better than those after PDP and other aforementioned conservative methods. The plasma 
not only serves as a fibrin tissue adhesive and a scaffold for cellular infiltration, but also promotes wound healing by increasing cellular proliferation, angiogenesis and collagen synthesis owing to a high concentration of plateletderived growth factors within the soft tissues adjacent to the fistulous tracts. Mechanical compression of the fistulous tract by injecting plasma into the tissues adjacent to anal fistulas is another PRP mode of action. Finally, it carries no risk of allergies and transmitting infections, since it is an autologous product. ${ }^{4}$

\section{Study Limitations}

This study has several limitations, such as a retrospective study design and a small sample size. However, the study might be considered in further meta-analyses.

\section{Conclusion}

Preliminary results of local PRP application in patients with recurrent, cryptoglandular anal fistulas showed a higher rate of fistula closure than PDP treatment. However, application of either PRP or PDP might be repeated several times if recurrences occur. Both methods could be combined with other conservative, sphincter-saving methods of surgery in a selected group of patients mainly with recurrent, high cryptoglandular anal fistulas. Such methods might be recommended as novel sphincter-saving procedures for recurrent anal fistulas.

\section{Ethics}

Ethics Committee Approval: The application of platelet-rich plasma as well as of a porcine-derived acellular dermal paste in anal fistulas was approved by the Bioethics Committee at the University.

Informed Consent: All participants/patients signed an informed consent before this study.

Peer-review: Externally and internally peer reviewed.

\section{Authorship Contributions}

Surgical and Medical Practices: J.H., J.C., T.B., Concept: T.B., Design: J.H., Data Collection or Processing: J.C., Analysis or Interpretation: B.K., Literature Search: J.C., Writing: J.H.

Conflict of Interest: No conflict of interest was declared by the authors.
Financial Disclosure: The authors declared that this study received no financial support.

\section{References}

1. Mei Z, Wang Q, Zhang Y, Liu P, Ge M, Du P, Yang W, He Y. Risk factors for recurrence after anal fistula surgery: a meta-analysis. Int J Surg 2019;69:153-164.

2. Parks AG, Gordon PH, Hardcastle JD. A classification of fistula-in-ano. Br J Surg 1976;63:1-12.

3. Göttgens KWA, Smeets RR, Stassen LPS, Beets G, Breukink SO. Systematic review and meta-analysis of surgical interventions for high cryptoglandular perianal fistula. Int J Colorectal Dis 2015;30:583-593.

4. Mussano F, Genova T, Munaron L, Petrillo S, Erovigni F, Carossa S. Cytokine, chemokine, and growth factor profile of platelet-rich plasma. Platelets 2016;27:467-471.

5. Greco KV, Francis L, Somasundaram M, Greco G, English NR, Roether JA, Boccaccini AR, Sibbons P, Ansari T. Characterisation of porcine dermis scaffolds decellularised using a novel non-enzymatic method for biomedical applications. J Biomater Appl 2015;30:239-253.

6. Karanikas I, Koutserimpas C, Siaperas P, Skarpas A, Karoubalis J, Velimezis G. Transrectal ultrasonography of perianal fistulas: a single center experience from a surgeon's point of view. G Chir 2018;39:258-260.

7. Norderval S, Rydningen MB, Falk RS, Arvid Stordahl A, Johannessen $\mathrm{HH}$. Strong agreement between interview-obtained and self-administered Wexner and St. Mark's scores using a single questionnaire. Int Urogynecol J 2019;30:2101-2108.

8. Lin H, Jin Z, Zhu Y, Diao M, Hu W. Anal fistula plug vs rectal advancement flap for the treatment of complex cryptoglandular anal fistulas: a systematic review and meta-analysis of studies with long-term follow-up. Colorectal Dis 2019;21:502-515.

9. Emile SH, Khan SM, Adejumo A, Koroye O. Ligation of intersphincteric fistula tract (LIFT) in treatment of anal fistula: An updated systematic review, meta-analysis, and meta-regression of the predictors of failure. Surgery 2020;167:484-492.

10. Garg P, Singh P. Video-Assisted Anal Fistula Treatment (VAAFT) in Cryptoglandular fistula-in-ano: a systematic review and proportional metaanalysis. Int J Surg 2017;46:85-91.

11. Hermann J, Banasiewicz T, Kołodziejczak B. Role of vacuum-assisted closure in the management of crohn's anal fistulas. Adv Skin Wound Care 2019;32:35-40.

12. Sugrue J, Mantilla N, Abcarian A, Kochar K, Marecik S, Chaudhry V, Mellgren A, Nordenstam J. Sphincter-sparing anal fistula repair: are we getting Better? Dis Colon Rectum 2017; 60: 1071-1077.

13. Jayne DG, Scholefield J, Tolan D, Gray R, Edlin R, Hulme CT, Sutton AJ, Handley K, Hewitt CA, Kaur M, Magill L. Anal fistula plug versus surgeon's preference for surgery for trans-sphincteric anal fistula: the FIAT RCT. Health Technol Assess 2019;23:1-76.

14. Himpson RC, Cohen CRG. An experimentally successful new sphincterconserving treatment for anal fistula. Dis Colon Rectum 2009;52:602-608. 